\title{
ESTIMASI PARAMETER MODEL GRAVITY DENGAN METODE PENAKSIRAN KUADRAT TERKECIL DAN FUNGSI HAMBATAN PANGKAT STUDI KASUS KABUPATEN SUKOHARJO
}

\author{
Haning Tri Indrawati ${ }^{1)}$, Syafi' ${ }^{2)}$, Slamet Jauhari Legowo ${ }^{3)}$ \\ 1) Mahasiswa Fakultas Teknik, Prodi Teknik Sipil, Universitas Sebelas Maret \\ 2),3) Pengajar Fakultas Teknik, Prodi Teknik Sipil, Universitas Sebelas Maret \\ Jl. Ir. Sutami 36 A, Kentingan Surakarta 57126; Telp. (0271) 634524, Fax 662118. \\ Email : haningtriindrawati19@,student.uns.ac.id
}

\begin{abstract}
Regional development have an impact on increasing the number of movements and have the potential to cause congestion, so greatest transportation planning is needed for dealing with transportation problems. One of the transportation planning methods is by using Origin-Destination Matrix (OD) to represent the movement patterns of an area, so MAT have an important role as consideration in determining transportation regulations. Thus, this research aims to determine the amount of trip distribution represented by $O-D$ matrix, determine $\beta$-value with least-square estimation method and power deterrence function using Matlab program, also intended to know the value of the validity test using coefficient determination ( $\left.R^{2}\right)$ based comparison between traffic flows from observation and modeling results. The traffic volume value was obtained by assigning the OD to the road network using User Equilibrium. Sukoharjo Regency is the study area in this research and divided the area into 36 zones consisting of 12 internal zones and 24 external zones. The process of estimating OD uses the Gravity Model generation and attraction restriction with EMME/3 program. The results showed the value of parameter $\beta$ is 0,0795. The total number from estimation of trip distribution Sukoharjo Regency 2021 was 16374 pcu/ hour with a validity level $\left(\mathrm{R}^{2}\right)$ of 0,8272 .
\end{abstract}

Keywords: EMME/3, Gravity Model, Least-Square, Origin Destination Matrix

\begin{abstract}
Abstrak
Perkembangan suatu daerah akan berdampak pada peningkatan jumlah pergerakan yang besar dan berpotensi akan menimbulkan kemacetan, sehingga perencanaan transportasi yang baik diperlukan untuk mengatasi permasalahan transportasi yang mungkin terjadi. Salah satu cara yang digunakan pada perancanaan transportasi, yaitu Matriks Asal Tujuan (MAT) yang dapat mencerminkan pola pergerakan dalam suatu wilayah, sehingga MAT mempunyai peranan penting sebagai pertimbangan dalam menentukan kebijakan. Oleh karena itu, penelitian ini bertujuan untuk mengetahui besar total distribusi pergerakan yang digambarkan oleh MAT, memperoleh nilai $\beta$ dari proses dengan metode kuadrat terkecil dan fungsi hambatan pangkat dengan bantuan program Matlab, selain itu juga untuk mengetahui nilai uji validitas menggunakan koefisien determinasi $\left(\mathrm{R}^{2}\right)$ berdasarkan perbandingan arus lalu lintas hasil pengamatan dengan arus lalu lintas hasil pemodelan. Nilai arus lalu lintas hasil pemodelan tersebut diperoleh dengan membebankan matriks baru ke jaringan jalan dengan metode pembebanan User Equilibrium. Kabupaten Sukoharjo merupakan wilayah kajian pada penelitian ini dan wilayah tersebut dibagi menjadi 36 zona yang terdiri dari 12 zona internal dan 24 zona eksternal. Pada proses pengestimasian MAT menggunakan model Gravity dengan batasan bangkitan dan tarikan yang diolah melalui program EMME/3. Hasil penelitian menunjukkan bahwa nilai parameter $\beta$ yang diperoleh sebesar 0,0795. Total jumlah estimasi pergerakan Kabupaten Sukoharjo 2021 sebesar 16.374 smp/jam dengan tingkat validitas $\left(\mathrm{R}^{2}\right)$ menunjukkan nilai sebesar 0,8272 .
\end{abstract}

Kata Kunci : EMME/3, Kuadrat Terkecil, Matriks Asal Tujuan, Model Gravity

\section{PENDAHULUAN}

Transportasi merupakan komponen penting dalam kehidupan manusia. Kinerja transportasi pada suatu daerah atau wilayah dipengaruhi oleh kondisi sosial maupun tingkat kepadatan penduduk pada daerah tersebut. Semakin berkembangnya suatu daerah akan berpengaruh terhadap perkembangan pendidikan, ekonomi, dan pertumbuhan penduduk sehingga menuntut manusia untuk melakukan pergerakan yang besar. Kondisi tersebut turut terjadi pada Kabupaten Sukoharjo karena letaknya yang strategis sehingga berpotensi dalam peningkatan jumlah pergerakan yang besar. Hal tersebut akan menjadi permasalahan yang kompleks pada sistem transportasi apabila tidak diatasi secara tepat. Oleh karena itu, diperlukan suatu perencanaan transportasi yang baik dan matang untuk meminimalisir permasalahan yang mungkin akan terjadi.

Pada perencanaan transportasi, dibutuhkan pemodelan transportasi sebagai penyederhanaan realita untuk memahami pola pergerakan yang terjadi pada suatu wilayah kajian. Salah satu tahap pemodelan pada transportasi yang akan diterapkan pada penelitian ini adalah distribusi pergerakan (trip distribution). 
Pada distribusi pergerakan, bangkitan pergerakan yang berasal dari zona asal dan pergerakan yang tertarik menuju zona tujuan akan didistribusikan di setiap zona asal dan tujuan. MAT dan garis keinginan (desire line) merupakan beberapa cara yang dapat menyatakan distribusi pergerakan tersebut.

Estimasi Matriks Asal Tujuan (MAT) pada penelitian ini menggunakan model Gravity dengan batasan bangkitan dan tarikan pergerakan. Pada proses pengestimasian MAT menggunakan model Gravity, terdapat nilai parameter $\beta$ yang harus diketahui. Proses penaksiran $\beta$ melalui proses kalibrasi Newton-Raphson dengan menggunakan metode penaksiran kuadrat terkecil dan fungsi hambatan pangkat sebagai ukuran aksesibilitas. Metode penaksiran kuadrat terkecil mengkalibrasi parameter $\beta$ yang belum diketahui dengan meminimumkan kuadrat dari selisih antara hasil pemodelan dengan data pengamatan. Apabila nilai parameter $\beta$ sudah didapatkan, maka akan memperoleh MAT hasil estimasi model Gravity yang selanjutnya akan dibebankan ke jaringan jalan. Hasil pembebanan tersebut akan diuji tingkat validitasnya dengan membandingkan arus lalu lintas hasil pemodelan dengan data arus lalu lintas hasil pengamatan di lapangan (traffic count).

Wilayah kajian pada penelitian ini adalah Kabupaten Sukoharjo. Letak Kabupaten Sukoharjo yang strategis sangat berpotensial untuk mendukung pertumbuhan dan perkembangan infrastruktur, sosial, dan ekonomi. Berdasarkan kondisi tersebut, disertai juga dengan pertumbuhan dan perkembangan yang pesat, tentunya akan berdampak pada peningkatan jumlah pergerakan yang berbanding lurus dengan permasalahan transportasi yang semakin kompleks. Oleh karena itu, penting untuk dilakukan penelitian studi kasus di Kabupaten Sukoharjo untuk dapat mengantisipasi permasalahan transportasi yang akan terjadi di masa yang akan datang.

\section{DASAR TEORI}

\section{Matriks Asal Tujuan (MAT)}

Matriks berdimensi dua dimana memuat besarnya pergerakan antar zona pada daerah tertentu merupakan definisi dari Matriks Asal Tujuan. Zona tujuan dinyatakan dengan kolom dan zona asal dinyatakan dengan baris pada MAT. Oleh karena itu, sel pada matriksnya menunjukkan besarnya arus yang berasal dari zona i (asal) menuju zona d (tujuan).

\section{Model Gravity dengan Batasan Bangkitan-Tarikan}

Menurut Tamin (2000), karakteristik bangkitan dan tarikan pergerakan pada model ini berkaitan dengan beberapa parameter zona asal, sebagai contoh aksesibilitas dimana sebagai fungsi waktu,jarak, dan biaya juga terkait dengan populasi dan nilai sel pada MAT. Model Gravity dalam bentuk matematis dapat dinyatakan pada persamaan [1].

$$
\text { Tid }=\text { Oi.Dd.Ai.Bd.f(Cid) }
$$

Keterangan :

Tid = Jumlah pergerakan dari zona asal i ke zona tujuan $\mathrm{d}$

$\mathrm{Ai}, \mathrm{Bd} \quad=$ Faktor penyeimbang untuk setiap zona asal $\mathrm{i}$ ke zona tujuan $\mathrm{d}$

Oi $\quad=$ Total pergerakan dari zona asal i

$\mathrm{Dd} \quad=$ Total pergerakan dari zona tujuan $\mathrm{d}$

$\mathrm{f}(\mathrm{Cid}) \quad=$ Fungsi umum biaya perjalanan (fungsi hambatan)

Pada kasus ini digunakan fungsi hambatan pangkat yang digunakan sebagai ukuran aksesibilitas dari zona asal i menuju zona tujuan d. Secara rinci, fungsi hambatan pangkat dapat dilihat pada persamaan [2].

$$
f\left(C_{i d}\right)=C_{i d}^{-\beta}
$$

Batasan bangkitan dan tarikan pergerakan ialah batasan yang diterapkan pada penelitian ini, sehingga diperlukan konstanta Ai dan Bd sebagai konstanta penyeimbang untuk memperkirakan jumlah pergerakan yang memiliki ketentuan atau syarat,batas yang,berbeda diantara konstanta Ai dan Bd yang dapat dilihat pada persamaan [3] dan [4].

$$
A i=\frac{1}{\sum_{d}\left(B_{d} \cdot D_{d} \cdot f_{i d}\right)}
$$


$B d=\frac{1}{\sum_{d}\left(A_{i} \cdot O_{i} \cdot f_{i d}\right)}$

\section{Metode Penaksiran Kuadrat Terkecil}

Proses mengkalibrasi parameter yang belum diketahui dengan meminimumkan kuadrat dari selisih antara hasil pemodelan (Tid) dan data observasi $\left(\widehat{T}_{\mathrm{id}}\right)$ merupakan gagasan utama dari metode kuadrat terkecil. Secara khusus, metode ini dapat dikatakan sebagai metode Kuadrat Terkecil Tidak Linier (KTTL). Metode KTTL ini diklasifikasikan menjadi 2, yaitu metode Kuadrat Terkecil Tidak Linier (KTTL) dan metode Kuadrat Terkecil Tidak Linier Berbobot (KTTLB). Secara matematis, metode kuadrat terkecil dapat dirumuskan seperti pada persamaan [5].

$$
S=\sum_{i=1}^{N} \sum_{d=1}^{N}\left[\frac{1}{\dot{T}}\left(T_{i d}-\hat{T}_{i d}\right)^{2}\right]
$$

$\dot{\mathrm{T}}=1$ untuk KTTL dan $\mathrm{T}=\widehat{T}_{i d}$ untuk KTTLB

Dengan demikian, untuk memperoleh nilai parameter yang belum diketahui didapat dengan membuat turunan pertama nilai Persamaan [4] terhadap parameter tersebut sama dengan 0, sehingga diperoleh persamaan [6].

$$
\frac{\partial S}{\partial \beta}=f=\sum_{i=1}^{N} \sum_{d=1}^{N}\left[\frac{2}{\dot{T}}\left(T_{i d}-\hat{T}_{i d}\right) \cdot \frac{\partial T_{i d}}{\partial \beta}\right]=0 \ldots \ldots \ldots[6]
$$

\section{Kalibrasi Newton-Raphson}

Parameter $\beta$ harus melalui proses kalibrasi dengan melakukan proses perhitungan secara berulang hingga nilai $\beta$ tersebut mencapai nilai batas konvergensinya. Pada kasus ini, metode kalibrasi Newton-Raphson merupakan proses kalibrasi dengan dasar pendekatan terhadap nilai $f(x)$ menggunakan deret Taylor sehingga didapatkan persamaan [7].

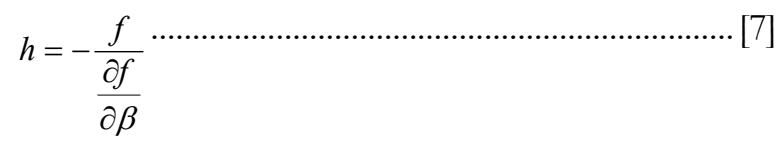

Selanjutnya nilai h pada persamaan [7] digunakan untuk mendapatkan pendekatan pada persamaan [8].

$$
\beta_{1}=\beta_{0}+h
$$

Keterangan :

$\beta_{1} \quad=$ nilai parameter $\beta$

$\beta_{0} \quad=$ nilai parameter $\beta$ awal

$f \quad=$ fungsi $\mathrm{f}$ terhadap parameter $\beta$

$\frac{\partial f}{\partial \beta} \quad=$ turunan fungsi $\mathrm{f}$ terhadap parameter $\beta$

\section{Indikator Uji Statistik}

Beberapa indikator uji statistik dapat menentukan tingkat validitas dari arus lalu lintas yang dihasilkan. Pada penelitian ini, koefisien determinasi $\left(\mathrm{R}^{2}\right)$ adalah salah satu indikator uji statistik yang digunakan dan dapat didefinisikan sebagai persamaan [9].

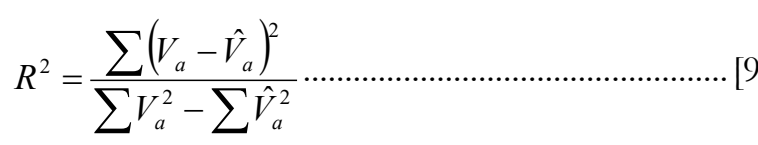


Keterangan:

$\widehat{\mathrm{V}}_{\mathrm{a}} \quad=$ arus lalu lintas dari hasil pengamatan

$\mathrm{V}_{\mathrm{a}} \quad=$ arus lalu lintas dari hasil pemodelan

\section{METODE PENELITIAN}

\section{Lokasi Penelitian}

Wilayah kajian pada penelitian ini dilakukan di Kabupaten Sukoharjo dengan membagi wilayah kajian yang terdiri atas 12 zona internal dan 24 zona eksternal, sehingga secara keseluruhan dibagi menjadi 36 zona. Pembagian zona internal didasarkan pada batas administrasi kecamatan Kabupaten Sukoharjo, sedangkan untuk zona eksternal yang mewakili arus keluar-masuk wilayah Kabupaten Sukoharjo. Penentuan lokasi pengamatan lalu lintas sebagai data primer menurut pertimbangan kondisi tata guna lahan sekitar, klasifikasi jalan, tingkat kepadatan, serta beberapa ruas jalan yang mewakili jaringan jalan Kabupaten Sukoharjo.

\section{Pengolahan Data}

Terdapat beberapa tahapan dalam melakukan pengolahan data lalu lintas. Tahapan pertama, yaitu mengubah konversi setiap tipe satuan kendaraan menjadi satuan mobil penumpang berdasarkan pedoman MKJI 1997. Selanjutnya, pengolahan data juga dilakukan perhitungan waktu tempuh kendaraan dan juga dilakukan perhitungan pada kapasitas jalan yang dihitung berdasarkan tipe jalan, lebar jalan, hambatan samping, panjang jalan, lebar bahu jalan, jarak kerb - penghalang, maupun jumlah penduduk dengan ketetapan dari MKJI 1997.

\section{Matriks Asal Tujuan Hasil Estimasi}

Data basis jaringan jalan yang telah melalui proses pengolahan data selanjurnya diinput dengan program EMME/3 pada fitur Network. Editor, akan memperoleh Matriks Asal Tujuan (MAT) hasil estimasi. Selanjutnya, memasukkan matriks awal (prior matrix) Kabupaten Sukoharjo pada software EMME/3. Setelah melalui tahapan tersebut, maka diperoleh hasil MAT baru dari analisis EMME/3 yang sebelumnya telah melalui uji validitas koefisien determinasi $\left(\mathrm{R}^{2}\right)$. MAT baru tersebut digunakan pada proses kalibrasi nilai $\beta$ dan kemudian dibebankan pada jaringan jalan, sehingga diperoleh arus,lalu,lintas dari hasil,pemodelan.

\section{Kalibrasi Nilai Parameter $\beta$}

Proses kalibrasi terus dilakukan secara berulang hingga nilai $\beta$ mencapai batas nilai,konvergen. Parameter $\beta$ diperoleh melalui proses kalibrasi Newton-Raphson dan metode penaksiran kuadrat terkecil dengan fungsi hambatan pangkat dengan program Matlab.

\section{Estimasi Matriks Asal Tujuan Hasil Model Gravity}

Model Gravity dengan batasan bangkitan dan tarikan pergerakan digunakan pada pengestimasian MAT tahun 2021 setelah memperoleh nilai $\beta$ pada proses kalibrasi Newton-Raphson. MAT hasil model Gravity tersebut merupakan gambaran dari total distribusi pergerakan pada suatu zona hasil,pemodelan.

\section{Pembebanan Arus Lalu Lintas}

Estimasi matriks asal tujuan 2021 hasil model Gravity akan dibebankan ke jaringan jalan Kabupaten Sukoharjo menggunakan program EMME/3 melalui tahap trip assignment metode User Equilibrium dengan pendekatan algoritma Frank Wolfe. Proses pembebanan ini akan memperoleh arus lalu lintas hasil pembebanan (hasil pemodelan) pada setiap ruas jalan wilayah kajian.

\section{Uji Validitas}

Uji validitas dilakukan berfungsi untuk memberikan gambaran suatu model mendekati realitas dan kondisi sebenarnya di lapangan, sehinga uji validitas dapat mengetahui seberapa besar perbedaan yang ditimbulkan. Semakin mirip suatu model dengan kondisi sebenarnya, maka nilai uji validitas tersebut akan menghasilkan angka mendekati 1. Koefisien determinasi $\left(\mathrm{R}^{2}\right)$ menjadi indikator uji statistik pada penelitian ini. 


\section{HASIL DAN PEMBAHASAN}

\section{Nilai $\beta$ sebagai Fungsi Hambatan}

Nilai $\beta$ diperoleh melalui proses kalibrasi Newton-Raphson dengan fungsi hambatan pangkat hingga nilai $\beta$ mencapai batas nilai konvergen, yaitu hingga nilai h mendekati nilai 0 . Proses kalibrasi nilai parameter $\beta$ menggunakan software MATLAB diperoleh nilai parameter $\beta$ sebesar 0,0795 dengan $\beta$ asumsi awal $\left(\beta_{0}\right)$ sebesar 0,08 .

\section{Distribusi Pergerakan Estimasi Matriks Asal Tujuan}

Desire line atau garis keinginan dapat menggambarkan besar pergerakan antar zona seperti pada Gambar 1. Desire line dapat menunjukkan atau mengetahui gambaran arah atau orientasi pergerakan. Desire line memiliki ketebalan garis yang berbeda karena ketebalan tersebut menyatakan jumlah arus pergerakan yang terjadi.

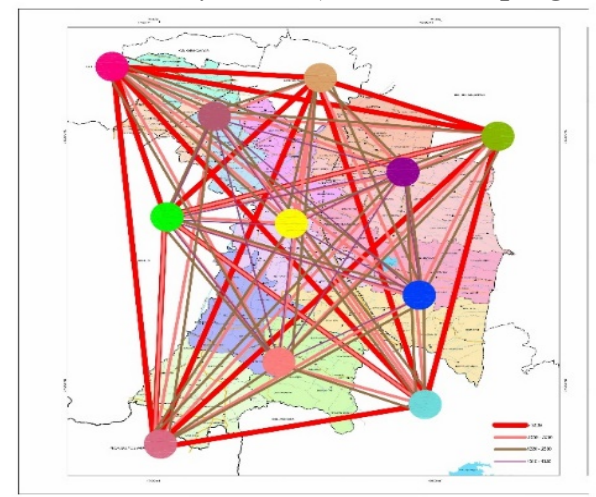

Gambar 1. Garis Keinginan (Desire Line) distribusi pergerakan Kabupaten Sukoharjo 2021

Pada gambar tersebut, terdapat 5 titik pergerakan internal digambarkan berdasarkan antar kecamatan sedangkan pada pergerakan eksternal terdapat 6 titik diluar batas Kabupaten Sukoharjo yang dibagi berdasarkan zona yang saling berdekatan. Pergerakan arus yang tinggi digambarkan dengan garis yang tebal, yaitu pada penelitian ini terjadi pada pergerakan eksternal ke eksternal.

Selain dapat dilihat dari desire line atau garis keinginan, besar total distribusi pergerakan dapat dilihat melalui tabel matriks dari hasil estimasi MAT 2021 dengan model Gravity dan menggunakan batasan bangkitan dan tarikan. MAT 2021 hasil estimasi model Gravity dapat dilihat pada Tabel 1.

Tabel 1. MAT Tahun 2021 hasil estimasi Model Gravity

\begin{tabular}{cccccccccccccc}
\hline $\mathbf{i} / \mathbf{j}$ & $\mathbf{7 0 1}$ & $\mathbf{7 0 2}$ & $\mathbf{7 0 3}$ & $\mathbf{7 0 4}$ & $\mathbf{7 0 5}$ & $\mathbf{7 0 6}$ & $\mathbf{7 0 7}$ & $\mathbf{7 0 8}$ & $\mathbf{7 0 9}$ & $\mathbf{7 1 0}$ & $\ldots$ & $\mathbf{7 3 6}$ & $\mathbf{0 i}$ \\
\hline $\mathbf{7 0 1}$ & 0 & 3 & 5 & 31 & 5 & 13 & 37 & 15 & 1 & 4 & $\ldots$ & 4 & $\mathbf{5 1 6}$ \\
$\mathbf{7 0 2}$ & 0 & 0 & 1 & 5 & 1 & 2 & 6 & 2 & 0 & 1 & $\ldots$ & 1 & $\mathbf{8 2}$ \\
$\mathbf{7 0 3}$ & 1 & 1 & 0 & 6 & 1 & 2 & 6 & 3 & 0 & 1 & $\ldots$ & 1 & $\mathbf{8 7}$ \\
$\mathbf{7 0 4}$ & 1 & 1 & 2 & 0 & 2 & 4 & 11 & 4 & 0 & 1 & $\ldots$ & 1 & $\mathbf{1 4 3}$ \\
$\mathbf{7 0 5}$ & 0 & 0 & 1 & 5 & 0 & 2 & 6 & 2 & 0 & 1 & $\ldots$ & 0 & $\mathbf{7 3}$ \\
$\mathbf{7 0 6}$ & 1 & 1 & 1 & 6 & 1 & 0 & 8 & 3 & 0 & 1 & $\ldots$ & 1 & $\mathbf{9 8}$ \\
$\mathbf{7 0 7}$ & 8 & 9 & 15 & 89 & 15 & 38 & 0 & 45 & 3 & 11 & $\ldots$ & 9 & $\mathbf{1 3 4 0}$ \\
$\mathbf{7 0 8}$ & 1 & 1 & 1 & 6 & 1 & 3 & 8 & 0 & 0 & 1 & $\ldots$ & 1 & $\mathbf{1 0 3}$ \\
$\mathbf{7 0 9}$ & 0 & 0 & 0 & 1 & 0 & 0 & 1 & 1 & 0 & 0 & $\ldots$ & 0 & $\mathbf{1 9}$ \\
$\mathbf{7 1 0}$ & 0 & 0 & 1 & 4 & 1 & 2 & 5 & 2 & 0 & 0 & $\ldots$ & 0 & $\mathbf{5 9}$ \\
$\ldots$ & $\ldots$ & $\ldots$ & $\ldots$ & $\ldots$ & $\ldots$ & $\ldots$ & $\ldots$ & $\ldots$ & $\ldots$ & $\ldots$ & $\ldots$ & $\ldots$ & $\ldots$ \\
$\mathbf{7 3 6}$ & 2 & 2 & 3 & 17 & 3 & 7 & 21 & 8 & 1 & 2 & $\ldots$ & 0 & $\mathbf{2 9 1}$ \\
$\mathbf{D d}$ & $\mathbf{8 8}$ & $\mathbf{1 0 7}$ & $\mathbf{1 8 1}$ & $\mathbf{1 0 6 2}$ & $\mathbf{1 8 0}$ & $\mathbf{4 5 1}$ & $\mathbf{1 2 0 5}$ & $\mathbf{5 1 8}$ & $\mathbf{3 2}$ & $\mathbf{1 3 1}$ & $\ldots$ & $\mathbf{1 1 4}$ & $\mathbf{1 6 3 7 4}$ \\
\hline
\end{tabular}


Berdasarkan MAT 2021 hasil estimasi model Gravity seperti pada tabel 1, total distribusi pergerakan Kabupaten Sukoharjo dihasilkan sebesar $16374 \mathrm{smp} /$ jam. Pergerakan antar zona dapat memberikan gambaran secara jelas pergerakan yang terjadi antara pergerakan dari internal menuju internal, internal menuju eksternal, eskternal menuju internal, dan eksternal menuju eksternal, sehingga dapat mencerminkan karakteristik yang terjadi di Kabupaten Sukoharjo pada tahun 2021. Pergerakan antar zona tahun 2021 dapat dilihat pada Gambar 2.

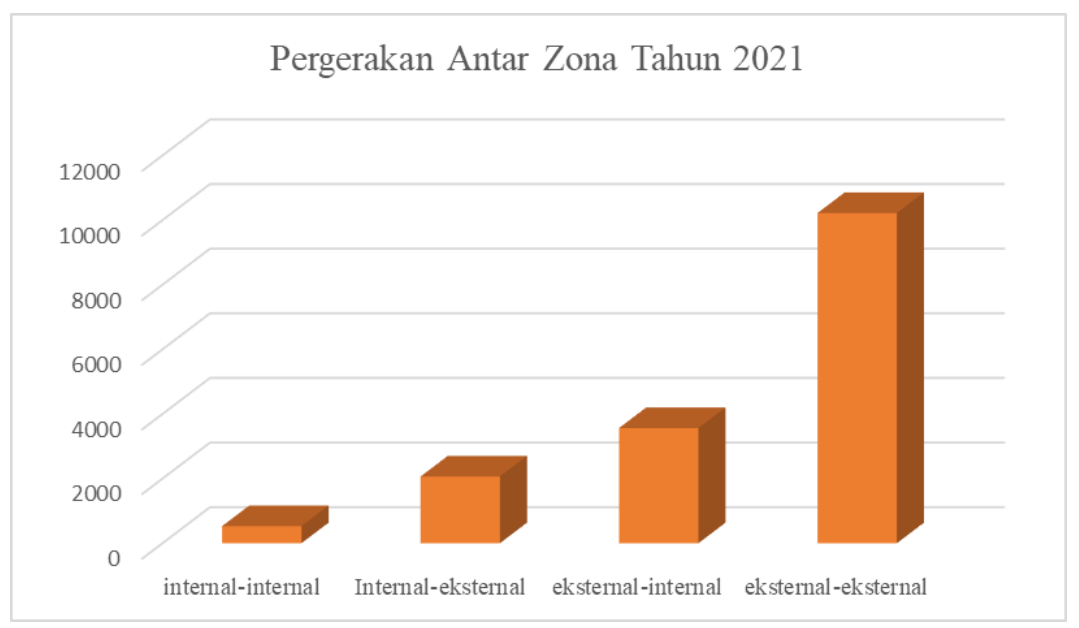

Gambar 2. Grafik pergerakan antar zona Tahun 2021

Besar pergerakan antar zona dalam bentuk presentase dan dalam satuan smp/jam dapat dilihat seperti pada tabel 2 berikut.

Tabel 2. Besar Pergerakan Antar Zona Tahun 2021

\begin{tabular}{lll}
\hline Zona Pergerakan & Total (smp/jam) & Presentase (\%) \\
\hline Internal-internal & 529 & 3,23 \\
Internal-eksternal & 2064 & 12,61 \\
Eksternal-internal & 3563 & 21,76 \\
Eksternal-eksternal & 10218 & 62,40 \\
\hline Total Pergerakan & $\mathbf{1 6 3 7 4}$ & $\mathbf{1 0 0}$ \\
\hline
\end{tabular}

Berdasarkan data tabel 2, total distribusi pergerakan Kabupaten Sukoharjo dihasilkan sebesar $16374 \mathrm{smp} / \mathrm{jam}$. Pergerakan eksternal-eksternal menjadi pergerakan dengan nilai arus lalu lintas tertinggi, yaitu dengan presentase 62,40\% dan besar distribusi pergerakan $10218 \mathrm{smp} / \mathrm{jam}$. Kemungkinan hal tersebut terjadi dikarenakan wilayah Kabupaten Sukoharjo yang berbatasan langsung dengan kabupaten/kota seperti, Kota Surakarta, Kabupaten Karanganyar, Kabupaten Wonogiri, Kabupaten Boyolali, Kabupaten Klaten, dan Kabupaten Gunung Kidul, sehingga wilayah Kabupaten Sukoharjo menjadi daerah yang sering dilewati atau dilalui oleh penduduk di luar wilayah Kabupaten Sukoharjo untuk melakukan kegiatan seperti bekerja, bersekolah, atau kegiatan lainnya yang berada di kabupaten/kota yang berbeda dalam rangka pemenuhan kebutuhan hidup.

Sebaliknya, pergerakan dengan arus lalu lintas terendah terjadi pada pergerakan dari internal menuju internal dengan presentase 3,23\%, yaitu dengan disitribusi pergerakan sebesar $529 \mathrm{smp} / \mathrm{jam}$. Hal tersebut terjadi dimungkinkan faktor jumlah penduduk usia kerja Kabupaten Sukoharjo yang relatif lebih sedikit dibandingkan dengan kabupaten/kota disekitarnya. Hal tersebut dapat memengaruhi pergerakan karena penduduk usia kerja lebih banyak melakukan pergerakan dengan tujuan bekerja untuk pemenuhan kebutuhan hidup. Pernyataan tersebut selaras dengan studi penelitian oleh Kharisma dkk (2016) dimana usia antara 15-40 tahun yang telah memiliki kendaraan pribadi akan melakukan pergerakan yang lebih mendominasi yang dilakukan pada waktu sibuk antara pagi, hingga siang hari. 


\section{Uji Validitas}

Uji validitas dilakukan berdasarkan perbandingan arus,lalu,lintas hasil observasi (traffic count) dengan arus, hasil pemodelan menggunakan koefisien determinasi $\left(\mathrm{R}^{2}\right)$ dengan bantuan program EMME/3 diperoleh sebesar 0,8272 dan terdapat galat sebesar 0,1728 . Berdasarkan syarat rentang koefisien determinasi, nilai $\mathrm{R}^{2}$ yang diperoleh menunjukkan hasil kategori rentang yang sangat tinggi.

\section{SIMPULAN}

Berdasarkan studi penelitian pada wilayah kajian Kabupaten Sukoharjo, hasil analisis serta pembahasan proses pengestimasian Matriks Asal Tujuan perjalanan terkait penelitian Estimasi Parameter Model Gravity dengan Metode Penaksiran Kuadrat Terkecil dan Fungsi Hambatan Pangkat Studi Kasus Kabupaten Sukoharjo, dapat disimpulkan bahwa :

1. Nilai parameter $\beta$ sebagai fungsi hambatan pada proses kalibrasi Newton-Raphson menggunakan bantuan program MATLAB diperoleh nilai sebesar 0,0795 .

2. Proses estimasi MAT menggunakan model Gravity dengan batasan bangkitan-tarikan diperoleh total distribusi pergerakan pada tahun 2021 sebesar $16374 \mathrm{smp} / \mathrm{jam}$. Pola pergerakan yang terjadi antar zona antara lain sebagai berikut :
a. Internal-Internal
b. Internal-Eksternal
: $3,23 \%$ atau $529 \mathrm{smp} / \mathrm{jam}$
b. Internal-Eksternal
: $12,61 \%$ atau $2064 \mathrm{smp} / \mathrm{jam}$
c. Eksternal-Internal
$: 21,76 \%$ atau $3563 \mathrm{smp} / \mathrm{jam}$
d. Eksternal-Eksternal
: $62,40 \%$ atau $10218 \mathrm{smp} / \mathrm{jam}$

Nilai pergerakan dengan arus tertinggi terjadi pada pergerakan eksternal ke eksternal, yaitu dengan presentase $62,40 \%$ dan pergerakan sebesar $10218 \mathrm{smp} / \mathrm{jam}$. Sebaliknya, pergerakan dengan nilai arus terendah terjadi pada pergerakan internal ke internal dengan presentase 3,23\%, yaitu dengan besar distribusi pergerakan 529 smp/jam.

3. Hasil uji validitas dengan koefisien determinasi mperoleh nilai $\mathrm{R}^{2}$ sebesar 0,8272 . Berdasarkan syarat rentang koefisien determinasi, nilai $\mathrm{R}^{2}$ yang diperoleh termasuk kategori validitas sangat tinggi.

\section{REKOMENDASI}

Adapun rekomendasi atau saran yang dapat penulis kemukakan untuk penyempurnaan penelitian selanjutnya terkait estimasi Matriks Asal Tujuan Perjalanan pada wilayah kajian Kabupaten Sukoharjo , yaitu :

1. Meningkatkan atau menambah jumlah titik survei ruas jalan yang ditinjau sehingga data yang telah diperoleh memberikan hasil yang mendekati dengan kondisi sebenarnya pada wilayah kajian.

2. Perlu adanya pembaharuan dan penyempurnaan terkait data ruas jalan berupa lebar dan panjang jalan, dan peta administrasi Kabupaten Sukoharjo oleh intansi terkait sehingga data yang diberikan sesuai dengan kondisi sebenarnya

\section{UCAPAN TERIMAKASIH}

Penulis mengucapkan terima kasih kepada Bapak Dr. Eng. Ir. Syafi'i , M.T, serta Bapak Slamet Jauhari Legowo, S.T., M.T sebagai dosen pembimbing pertama dan kedua yang berkenan untuk membimbing penulis dalam penyusunan penelitian ini. Ucapan terimakasih penulis juga ditujukan orang tua, saudara, rekan, serta pihak lainnya yang turut membantu penulis pada penyusunan tugas akhir ini.

\section{REFERENSI}

Pemerintah Repulik Indonesia, 2004, “Undang-Undang Republik Indonesia Nomor 38 Tahun 2004 Tentang Jalan. Pemerintah Republik Indonesia", Jakarta.

Tamin, O. Z., 2000, "Perencanaan \& Pemodelan Transportasi".

Direktorat Jenderal Bina Marga Departemen Pekerjaan Umum RI, 1992, "Standar Perencanaan Geometrik Untuk Jalan Perkotaan”, Direktorat Pembinaan Jalan. Kota Jakarta.

PUPR, K., 1997, "Highway Capacity Manual Project (HCM)", Manual Kapasitas Jalan Indonesia (MKJI). Vol. 1 No I, pp. 564.

Tamin, O. Z., 2000, "Perencanaan \& Pemodelan Transportasi. Edisi Kedua”. Institut Teknologi Bandung, Bandung. 